\title{
The past and future contributions of research on Japanese management
}

\author{
Shige Makino ${ }^{1} \cdot$ Derek Lehmberg $^{2}$
}

Published online: 23 December 2019

(c) Springer Nature Limited 2019

\begin{abstract}
Publications on Japanese business have decreased as Japan continued to experience slow economic growth and fell behind other countries in competitiveness. While implementation of "Abenomics" policies has resulted in some encouraging economic growth, Japan faces additional challenges stemming from demographic change and globalization. These environmental trends along with technological change including digitalization and artificial intelligence appear likely to transform Japanese business and Japanese managerial practice as we know them, presenting new opportunities to learn from Japan. In this special issue, we reflect on the impact of past research on Japanese management, present several studies with implications about how Japanese business is changing, and pose questions for future research.
\end{abstract}

Keywords Japan · Japanese management - Globalization · Technological change

In the 1980s, seemingly unstoppable Japanese manufacturers gained major positions in global markets, taking many Western competitors by surprise. The topic of "Japanese management" boomed and gathered interest in both academic and business communities. Increased interest led to rapid growth in the number of publications on the Japanese business system and on specific Japanese management practices. These included articles and books with titles such as: What We Can Learn From Japanese Management (Drucker 1971), as Japan as Number One: Lessons for America (Vogel 1979), Theory Z: How American Business Can Meet the Japanese Challenge (Ouchi 1981), The Mind of the Strategist: The Art of Japanese Business (Ohmae 1982), The Art of Japanese Management: Applications for American Executives (Pascale and

Derek Lehmberg

derek.lehmberg@ndsu.edu

Shige Makino

makino@baf.cuhk.edu.hk

1 Chinese University of Hong Kong Business Schoool, Shatin, Hong Kong

2 North Dakota State University, Fargo, ND, USA 
Athos 1982), and Kaisha, the Japanese Corporation (Abegglen and Stalk 1985). The common message of these publications was simple: American executives can and should learn from Japanese firms.

From the mid-1990s to the early 2010s, however, Japanese firms encountered serious economic setbacks triggered by (1) the bursting of Japan's real estate bubble in early 1990s, (2) the Asian currency crisis in the late 1990s, and (3) the global financial crisis and recession of 2007-2009. Japan experienced a prolonged economic recession over a period often referred to "the lost decades." Since late 2012, Japanese economic indicators began to finally show signs of economic recovery, influenced by a series of economic stimulus measures taken by Shinzo Abe's Cabinet, and frequently referred to as "Abenomics." Despite the recent economic recovery, the lost decades resulted in a significant decrease in Japan's competitiveness. In 1989, when IMD, a Switzerland-based business school, first published its national competitiveness ranking (The World Competitiveness Yearbook), Japan was in the number one position, while Germany was second, and the US, third. The most recent report (2019) ranked Japan at the 30th most competitive, behind many countries and regions in Asia which had previously ranked far below it. For example, Singapore was currently ranked 1st, Hong Kong 2nd, China 14th, Taiwan 16th, Malaysia 22nd, Thailand 25th, and South Korea 28th. Indonesia, currently ranked 32nd, has been catching up with Japan very quickly and is expected to overtake it soon. Major countries in the Middle-East are also ranking higher than Japan. The report ranked the UAE as 5th, Qatar 10th, Israel 24th, and Saudi Arabia 26th. Ironically, Japan has been a major supplier of ODA to many of these countries.

The decline in Japan's competitiveness as an economic power is also reflected in the declining trend in publications of scholarly research on Japanese business and management. Figure 1 shows the historical trend of publication of research on Japanese business and management in academic journals in comparison to publications on Chinese business and management.

We can see that the number of publications began to increase from the late 1980s to the early 1990s when Japan enjoyed the economic boom or "bubble economy" and the first peak appeared in the mid-1990s. After declining in the late 1990s, the number of publications began to increase again, reaching the second peak in the late 2000s. Subsequently, the volume of publications began to decline again in the second half of the 2000s, coinciding with the recession following the global financial crisis that began around the end of 2008. Chinese business and management publications provide a clear contrast to Japan-related research. In the 1990s, academic publications on Chinese business were relatively rare. Since the late 2000 s, however, they have increased dramatically and currently outpace Japan-related publications by several times.

Is research into Japanese business fading out? We say No. However, it is important for us to consider how Japanese business research may contribute to the greater literature of business and management studies and develop a stronger, more impactful position. Indeed, this is the main purpose of this special issue. 


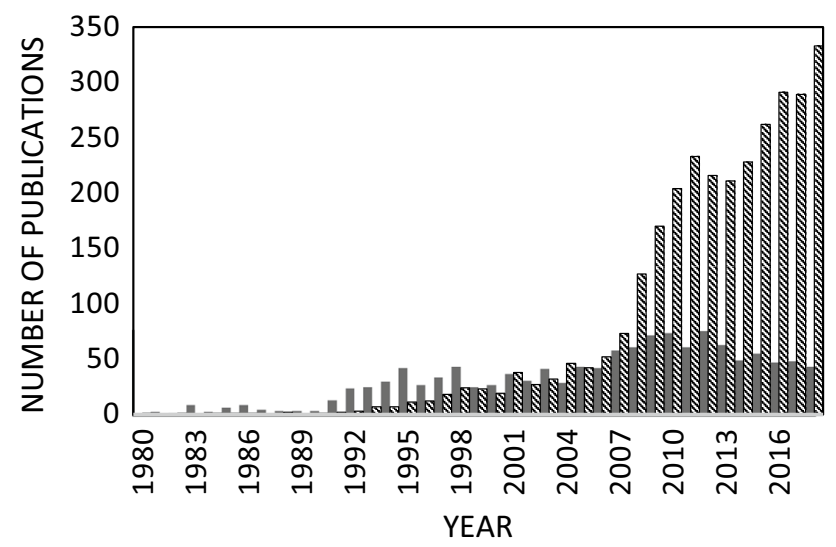

Japan China

Fig. 1 Comparison of the number of publications on Japanese and Chinese business and management. Note The data were selected using Web of Science with topic of either Japanese (Chinese) business or Japanese (Chinese) management published in articles in English in the Web of Science field, MANAGEMENT OR BUSINESS

\section{Types of Japanese business research}

Reflecting on research into Chinese business, Barney and Zhang (2009, p. 15) argued that scholars can contribute to the literature by either developing a theory of Chinese management, which focuses on applying and refining theories developed elsewhere in a Chinese context, or developing a Chinese theory of management, which focuses on creating explanations for the existence of Chinese management phenomena that are uniquely Chinese. We believe these insights apply to research on Japanese business and management as well. We argue that scholars can make contributions to the literature through the following three options:

- Developing a theory of Japanese management-applying and examining a general theory of business and management in the Japanese context.

- Developing a Japanese theory of management-understanding unique characteristics of business and management in Japan.

- Developing a general theory of management from observations of Japanese experiences and practices in business and management.

The first type of research appears mostly in the form of large sample statistical analyses of the data of Japanese firms collected from a survey or the database. Researchers in this category typically represent those who studied 'scientific' research methodology and advanced statistical techniques in doctoral programs in North America and aim primarily at publishing international peer-reviewed journals. This approach has become increasingly popular among business scholars in 
recent years due to the fact that journal publications are counted as tenure and promotion requirements.

The second type of study is presented in the form of a qualitative analysis such as case studies or ethnography of specific companies or business practices in Japan. This approach has long dominated the tradition of mainstream research in the Japanese academic community. Researchers in this category tend to focus on "understanding" the phenomena of interest rather than developing new theories or examining theories developed elsewhere. This approach tends to produce interdisciplinary research such as anthropology and history but has limited contributions to the development of general theory of business and management.

The third type of research is relatively rare but has been promoted by a few early scholars such as Masahiko Aoki, William Ouchi, and Ikujiro Nonaka. They developed a general theory of management based on detailed observations of Japanese companies that can be applied to non-Japanese companies. These scholars have developed new theories by rejecting the assumptions that underlie traditional theories developed primarily in the West, through close observation of Japanese firms. Unfortunately, we have not seen many studies published in this category in recent years.

Scholars of Japanese business and management have made, and will continue to make, contributions to the literature in one of the above three approaches. We believe being cognizant of these different approaches can help researchers identify new areas for research. In the past, as Westeney argues in this volume, research in Japanese business has sometimes fallen into a "uniqueness trap"-in other words, observations made in the Japanese context failed to gain interest outside of Japan because they were construed as being "Japan-specific" and therefore not generalizable to other contexts. When we consider the different approaches to conceptualizing Japanese business, it can help us identify new opportunities to learn from our observations, for example, by asking other questions, such as: what does this tell us about the boundary conditions of general theory?

\section{Articles in this special issue}

This special issue includes six articles which examine the impact of research on Japanese business and collectively provide evidence about how Japanese business is adjusting to major changes in the environment. Masaaki (Mike) Kotabe (2020) and Eleanor Westeney (2020), two most influential scholars of Japanese business studies, have contributed guest essays to this special issue. Mike and Eleanor provide a comprehensive review and assessment of the historical development and the impact of Japanese business research.

Eleanor's article examines the impact that studies of Japanese Business have made on practice and management theory. These impacts have indeed been significant, yet, as Eleanor argues, greater contributions may have not been attained because research on Japanese business often fell into a "uniqueness trap," considered as Japan specific and therefore not relevant to other circumstances. 
Mike's article takes a different direction, arguing that the successes of Japanese management in the 1970s through the 1990s was due to the strong fit between Japanese management practices and the economic, cultural, legal, and technological environment at the time. Furthermore, he argues, Japanese firms no longer benefit from unique business practices, as the useful practices have largely been copied and adapted by other firms.

In addition to the two invited papers, this special issue also includes four research articles. As a group, these papers update our knowledge about several well-known areas of Japanese business and begin to examine new areas emerging as Japanese business enters a new era of change.

Kosaka et al. (2020) examine change in vertical keiretsu-a uniquely Japanese relationship between a central end product manufacturer and supplier firms-in response to changes in the competitive environment. Common in the automotive and electronics industries, keiretsu have enabled Japanese firms to efficiently deliver high quality products. However, economic pressures stemming from changes in the environment have caused many of the central firms to reconsider the keiretsu system. Kosaka et al. (2020) find that while keiretsu relationships have changed to incorporate the market mechanism, these relationships continue to be important.

Sakawa and Watanabel (2020) study the Japaense main bank system, a Japanese corporate governance mechanism differing from Western, market-based approaches. Main banks are primary providers of capital to their client firms and hold long-term relationships, including equity participation. This relationship gives main banks access to client financial information that is not made public, and reduces the information asymmetry between the bank and borrowing client. Observing that companies having main bank relationships exhibit less accounting conservatism than those borrowing on the commercial market, Sakawa and Watanabel (2020) conclude that this form of Japanese governance is effective at monitoring firms.

Taken together, Kosaka et al. (2020) and Sakawa and Watanabel (2020) suggest that Japanese business, although affected by the environment and the practices of foreign competitors, continues to maintain uniquely Japanese practices. Rather than being replaced by foreign practices, it appears that Japanese business practices have evolved over time, sometimes turning into new, hybrid practices incorporating aspects of the traditional Japanese practice and foreign concepts.

The following two papers examine the relationship between Japanese and non-Japanese employees in Japanese firms. Oki (2020) looks at the relationship between decision-making authority and performance in foreign subsidiaries of Japanese firms. Japanese firms have long been noted for their ethnocentric management practices, with decision-making authority in international subsidiaries often falling in the hands of Japanese expatriates. Oki (2020) finds that expatriate decision-making authority is positively related to subsidiary performance although local employee decision-making authority is not related to performance, and headquarter decision-making authority is negatively related. This suggests that expatriates are able to bring valuable firm and Japan-specific knowledge to bear while they incorporate an understanding of the local context. However, Oki (2020) also finds that the relationship between expatriate decision-making 
authority and performance weakens in subsidiaries which have longer operating experience and in subsidiaries which have low export ratios and do not need an understanding of the Japanese home market.

Huang et al. (2020) examine the attractiveness of Japanese employers to international students. Given Japanese population demographics, the question of how to attract and effectively incorporate foreign employees is an important question for firms operating in Japan. However, Japanese human resource management has tended to follow uniquely Japanese practices, and diversity and inclusion practices remain uncommon. The findings of Huang et al. (2020) suggest that firms need to create a sense of belongingness which includes their foreign employees while also valuing their uniqueness as individuals. Furthermore, international employees prefer performance-based pay over seniority-based pay, since they may consider other opportunities including returning to their home country before they would be able to enjoy the benefits of seniority. Overall, the changes required by Japanese employers to effectively attract and retain international employees are significant. This includes a greater understanding of the national, cultural, linguistic, and educational diversity of potential candidates.

\section{Japanese business research-a way forward}

This special issue provides an overview of our understanding of Japanese business practice and how it has developed over time. It offers insights on where Japanese business practices are headed, suggesting that they will continue to evolve amidst a tension between traditions and uniquely Japanese ways of doing things on the one side, and pressures to internationalize and rationalize on the other. At the same time, many questions remain unanswered. Japanese firms, like those in any other countries, are entering the new era of globalization and digital transformation. In closing, we would like to pose several forward looking questions of interest:

1. Will further advancements of IT blur the boundaries between Japanese firms and business groups (e.g., keiretsu) thereby facilitating sharing of proprietary resources among the firms?

2. Will globalization and demographic changes force Japanese firms, regardless of their size or business domain, to further globalize their operations and to adopt global standards in their management practices?

3. How will advancements in AI affect Japanese firms' long-term investments in human capital?

In the midst of these major changes in the technological and global environment, we believe these are interesting times for observers and scholars of Japanese business. We trust that future research on Japanese business will continue to bring fresh insights relevant inside and outside of Japan. 


\section{References}

Abegglen, J. C., \& Stalk, G. (1985). Kaisha, the Japanese corporation. New York: Basic Books.

Barney, J. B., \& Zhang, S. (2009). The future of Chinese management research: A theory of Chinese management versus a Chinese theory of management. Management and Organization Review, 5(1), $15-28$.

Drucker, P. F. (1971). What we can learn from Japanese management. Harvard Business Review, MarchApril, 110-122.

Huang, L., Yang, Y., \& Sekiguchi, T. (2020). Attractiveness of Japanese firms to international job applicants: The effect of belongingness, uniqueness, and employment patterns. Asian Business \& Management, 19(1). https://doi.org/10.1057/s41291-019-00068-0.

Kosaka, G., Nakagawa, K., Manabe, S., \& Kobayashi, M. (2020). The vertical keiretsu advantage in the era of Westernization in the Japanese Automobile Industry: Investigation from transaction cost economics and a resource-based view. Asian Business \& Management, 19(1). https://doi.org/10.1057/ s41291-019-00074-2.

Kotabe, M. (2020). Japanese management and the climate of the time. Asian Business \& Management, 19(1). https://doi.org/10.1057/s41291-019-00078-y.

Ohmae, K. (1982). The mind of the strategist: The art of Japanese business. New York: McGraw-Hill.

Oki, K. (2020). Factory performance and decision-making authority between headquarters, expatriates, and local employees in Japanese MNCs in Southest Asia. Asian Business \& Management, 19(1). https://doi.org/10.1057/s41291-018-00054-y.

Ouchi, W. G. (1981). Theory Z: How American business can meet the Japanese challenge. Reading, MA: Addison-Wesley.

Pascale, R. T., \& Athos, A. G. (1982). The art of Japanese management: Applications for American executives. New York: Warner Books.

Sakawa, H., \& Watanabel, N. (2020). Main bank relationship and accounting conservatism: evidence from Japan. Asian Business \& Management, 19(1). https://doi.org/10.1057/s41291-019-00071-5.

Vogel, E. F. (1979). Japan as number one: Lessons for America. Cambridge, MA: Harvard University Press.

Westney, E. (2020). Reflecting on Japan's contributions to management theory. Asian Business \& Management, 19(1). https://doi.org/10.1057/s41291-019-00079-x.

Publisher's Note Springer Nature remains neutral with regard to jurisdictional claims in published maps and institutional affiliations. 